International Journal of Engineering \& Technology, $7(4.34)(2018) 306-308$
International Journal of Engineering \& Technology
SPC
Website: $w w w . s c i e n c e p u b c o . c o m / i n d e x . p h p / I J E T$
Research pa

\title{
Bandung City Government Performance, Balance Scorecard Model
}

\author{
Nuryaman, Mohd Haizam Mohd Saudi*, Mariana Rachmawati, Karhi Nisjar S. \\ School of Graduate Studies, Widyatama University, Indonesia \\ *Corresponding author E-mail: haizam@widyatama.ac.id
}

\begin{abstract}
The purpose of this study was to measure the performance of the Bandung City government offices using the Balance Scorecard model. Descriptive analysis method is used to find out the description of each variable stated in the questionnaire on service, internal operation process, learning and growth and financial performance. The survey was carried out in 2016. The results showed the performance of 17 government service offices of Bandung City with the balanced scorecard method included in the good performance category.
\end{abstract}

Keywords: Balanced Scorecard; performance.

\section{Introduction}

The performance of the local government of Bandung City has become a public concern, because a number of performance indicators have not been achieved in the last 2 (two) years 2014-2015, and service performance in Bandung city from year to year indicates a decrease [4]. But on the other hand, the Mayor of Bandung released the performance of the Bureaucracy (version of Ministry regulation, no 53) and public service (version of the Ombusman) Bandung City Government ranked well [7].

The Minister of Administrative Reform has issued Ministry Regulation No. 53 of 2014 concerning Technical Procedures and Technical Guidelines for Reporting on Performance and Procedures for Reviewing Government Institution Performance Reports (LKIP report). LKIP report version performance measurement is not comprehensive because it emphasizes on only two aspects; finance and organization. Based on the explanation above, there is a phenomenon of differences in the results of the measurement of the performance of the PEMDA (Local Government) of the City of Bandung between one another. This is due to the different ways and dimensions of measurement performance. LKIP focused more on measuring the performance of the financial dimension, while Ombusman measured the dimensions of public services and customer satisfaction, so that a comprehensive performance measurement was needed.

One of the more comprehensive performance measurement systems is model Balanced Scorecard (BSC). BSC is a performance measurement method that measures financial and non-financial performance [6]. The implementation of BSC government or public sector organizations will be able to explain its mission to the community and can identify indicators of community satisfaction more objectively, and be able to identify work processes and the quality of human resources needed in achieving its mission [5]. Government services office performance in Bandung City using the BSC approach [2]. This research was conducted on all service Offices located in the City of Bandung.

\section{Theoretical Framework}

Performance measurement is the process of evaluating work results based on pre-determined goals and objectives concerning: efficiency, use of resources, quality of products or services, comparison of results of activities with targets, and effectiveness of policies. This progress assessment can be in the form of financial and non-financial measures. One way to measure performance comprehensively is the Balance Scorecard (BSC) method.

The BSC translates organizational vision and strategy into a comprehensive set of measures, and provides a framework for measurement and strategy management systems [6]. The BSC provides a comprehensive set of performance measurements, divided into four perspectives namely: (1) learning and growth, a measure of the quality of human resources (2) internal operating processes, a measure of the quality of business processes; (3) customers, measures of service quality; and (4) Finance [9].

The application of the balanced scorecard to public organizations including government, requires some adjustments because public sector organizations and the business sector have different vision and mission. One of the main stakeholders of the public sector is the community and certain groups, while the main stakeholders of the business sector are consumers and shareholders. The government is in charge of providing services and values to the public and taxpayers. Government development programs must provide results in accordance with what is needed by the community [1]. BSC describes organizational performance in four perspectives [6]: (1) learning and growth; this perspective identifies infrastructure, rules and procedures, the human resources that the organization builds in creating growth and increasing long-term performance, (2) Internal business processes; This perspective focuses on the improvement and development of internal processes that have an impact on community satisfaction and achievement, (3) Customer satisfaction. In the customer perspective, public sector organizations focus on fulfilling community satisfaction through the provision of quality goods and public services, (4) Financial perspective. The financial perspective is very important in 
providing economic direction, goals and actions that have been taken by the government for the benefit of the people's welfare.

Based on the description above, this research framework can be described as follows:

Table 1: Balanced Scorecard as a Performance Measurement Tool for the Bandung City Office

Learning and growth perspective:

1. Organizational Aspect:

2. Employee capability

3. Information System Capability

4. Motivation, Empowerment and Alignment

Customer Perspective

Main Dimensions of Service:

1. Tangibility

2. Reliability

3. Responsiveness

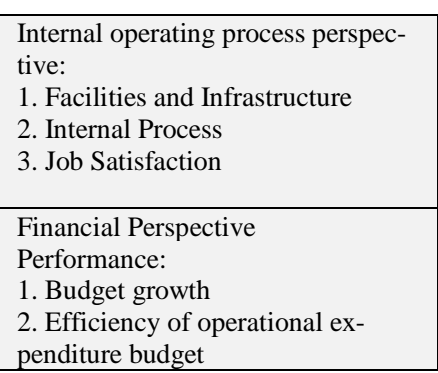

4. Assurance

5. Empathy

\section{Methodology}

The population used is 17 services offices in government the city of Bandung because of the total population of 17 offices in the local government of Bandung City. This study uses census methods. The author uses data collection techniques by distributing questionnaires with a Likert scale for measuring non-financial dimensions. The survey was carried out in November 2016. The financial performance data using the 2011-2014 Budget Realization Report data. The statistical model used is descriptive statistics.

\section{Operationalization of Variable}

Table 2: Operationalization of BSC variable

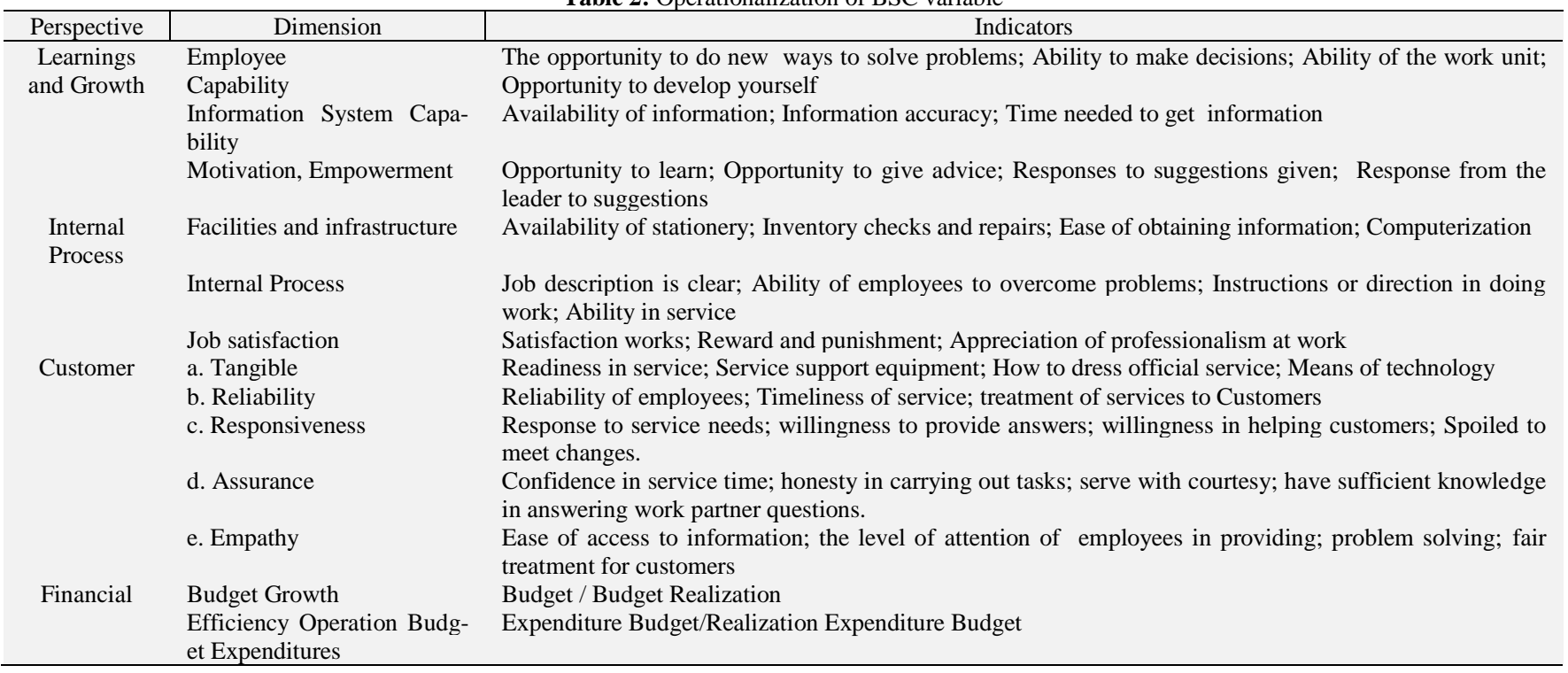

The fourth dimension (BSC) in the Likert scale is transformed into several categories as:

\begin{tabular}{ccc}
\hline Not Good & $\leq 55 \%$ & $1,9-26$ \\
Very Bad & $1-1,8$ \\
\hline
\end{tabular}

\begin{tabular}{c|c|c}
\multicolumn{3}{c}{ Table 3: Measurement scale } \\
\hline Category of & Budget & Performance \\
Achievement & Absorption & Final Value \\
\hline Very good & $85 \%-100 \%$ & $4,3-5$ \\
Good & $70 \%-<85 \%$ & $3,5-4,2$ \\
Fair & $55 \%-<70 \%$ & $2,7-3,5$ \\
\hline
\end{tabular}

\section{Results and Discussion}

The results of the overall performance of the Bandung City Office during 2011-2014 based on Balance scorecard method can be seen in the following table.

Table 4: Recapitulation of results of service performance measurement in Bandung city with the balanced scorecard method

\begin{tabular}{|c|c|c|c|c|c|c|c|c|}
\hline No. & Department & $\begin{array}{l}\text { Growth and Learn- } \\
\text { ing }\end{array}$ & $\begin{array}{l}\text { Internal Opera- } \\
\text { tion }\end{array}$ & Customer & Financial & Average & $\%$ Average & Category \\
\hline 1 & $\begin{array}{l}\text { Government Servant Registration } \\
\text { and Population Service }\end{array}$ & 4,56 & 5,00 & 3,66 & 5,00 & 4,56 & 91,10 & $\begin{array}{l}\text { Very } \\
\text { Good }\end{array}$ \\
\hline 2 & Department of Transportation & 3,86 & 4,69 & 2,93 & 5,00 & 4,12 & 82,40 & Good \\
\hline 3 & public health Office & 4,00 & 4,00 & 3,38 & 5,00 & 4,10 & 81,90 & Good \\
\hline 4 & $\begin{array}{l}\text { Office of Communication and } \\
\text { Information }\end{array}$ & 4,19 & 3,42 & 3,71 & 5,00 & 4,08 & 81,60 & Good \\
\hline 5 & Cooperative Office, UKM & 3,92 & 4,00 & 3,20 & 5,00 & 4,03 & 80,60 & Good \\
\hline 6 & Culture, Tourism Agency & 3,67 & 3,67 & 3,22 & 5,00 & 3,89 & 77,80 & Good \\
\hline 7 & Regional Financial and Asset & 4,03 & 4,31 & 4,00 & 3,00 & 3,84 & 76,70 & Good \\
\hline 8 & Management Service & 3,53 & 3,56 & 3,62 & 4,50 & 3,80 & 76,05 & Good \\
\hline 9 & Dinas Bina Marga and Pengairan & 3,46 & 3,86 & 2,88 & 5,00 & 3,80 & 76,05 & Good \\
\hline 10 & Tax Service Office & 3,36 & 3,36 & 3,17 & 5,00 & 3,72 & 74,45 & Good \\
\hline 11 & labor offices & 3,25 & 2,92 & 3,15 & 5,00 & 3,58 & 71,60 & Good \\
\hline 12 & $\begin{array}{l}\text { Fire Prevention and Control } \\
\text { Agency }\end{array}$ & 3,36 & 3,36 & 2,80 & 4,50 & 3,51 & 70,10 & Good \\
\hline 13 & social services & 3,56 & 3,00 & 3,46 & 4,00 & 3,51 & 70,10 & Good \\
\hline 14 & Cemetery and Garden Service & 3,64 & 3,00 & 3,32 & 4,00 & 3,49 & 69,80 & Fair \\
\hline 15 & $\begin{array}{l}\text { Agriculture Service and Food } \\
\text { Security }\end{array}$ & 3,67 & 4,22 & 2,98 & 3,00 & 3,47 & 69,35 & Fair \\
\hline 16 & Lay Out and Create Creation & 3,36 & 3,36 & 3,07 & 4,00 & 3,45 & 68,95 & Fair \\
\hline
\end{tabular}




\begin{tabular}{lllllrrrr}
\hline 17 & education authorities & 2,42 & 2,39 & 2,98 & 5,00 & 3,20 & 63,95 & Fair \\
& Average & 3,64 & 3,65 & 3,27 & 4,65 & 3,80 & $76,05 \%$ & Good \\
\hline
\end{tabular}

Based on Table 4, the average results of the performance measurement of 17 Service offices in Government Bandung City from the whole perspective of the Balanced Scorecard which includes learning and growth perspectives, internal operating process perspective, customer perspective, financial perspective that is equal to 3.80 or $76.05 \%$. This is the sum of the average final performance values. Based on the calculation of the overall performance score range, the value is in the good category. With the lowest average value is in the perspective of the customer with an average value of 3.27 and the highest average value is in the financial perspective with an average value of 4.65 .

The financial performance of the city of Bandung in the measurement period is classified as very good. This shows that economic development in the City is considered successful, in accordance with data from the Central Statistics Agency (BPS) that the average economic growth of Bandung City in the 2011-2014 observation period reached $8 \%$ [3]. The economic growth of the city of Bandung is above the national economic growth which only reached an average of $6.6 \%$. However, the Bandung city government still needs to improve services to the community, because the survey shows that community satisfaction with new public services is quite satisfactory.

The Office that has the highest average value of all services in the City of Bandung is the Population and Civil Registration Service office with an average value of 4.56 or $91.10 \%$ which means that it is in a very good category. It can be said that the performance of the Population and Civil Registration Service office in the city of Bandung by being measured using a balanced scorecard is very good. Whereas, for the Office that has the lowest average value of the 17 Offices in the City of Bandung which is viewed from four perspectives namely the Education Office at 3.20 or $63.95 \%$, which means that the performance of the Education Office is considered good enough [8].

The performance of the education office is categorized as unsatisfactory. The community cares about the education of the city of Bandung has expressed its complaints over the lack of service in the education service in 2013. This reinforces the results of the survey in the observation period that the Bandung City Education Office performed the lowest among 17 other Department.

\section{Conclusion}

Based on the analysis, the final performance of the 17 services in the city of Bandung using the Balanced Scorecard method is categorized as Good. The Office that has the highest performance assessment results is the Office of Population and Civil Registration with the Very Good category, while the agency that has the lowest performance assessment results is the Education Office with the Good Enough category [10].

Learning and growth performance, as well as the internal operational process of the Office in Bandung City are in good category. The highest value of both perspectives on this performance was obtained by the Population and Civil Registration Service, while the lowest value was from the Education Office. Customer perspective performance is categorized quite well, has the lowest average value compared to other perspectives. The Office that has the highest average value in the customer perspective is the Regional Financial and Asset Management Office, while the lowest average value is the Office of Social Affairs. Financial performance is very good; this shows good financial management.

\section{References}

[1] Financial and Development Supervisory Agency (BPKP). 2003 Balanced Scorecard, Its Application to Public Sector Organizations: An Introduction. BPKP.
[2] Budiwidarto, A. 2007. Measurement of Performance of Jakarta II State Treasury Service Office with Balanced Scorecard Approach. Thesis, University of Indonesia.

[3] Biro Pusat Statistik Kota Bandung. https://bandungkota.bps.go.id).

[4] Bagian Organisasi dan Pemberdayaan Aparatur Daerah Setda Kota Bandung. http://lakip.bandung.go.id/portal/home.

[5] Effendi, R. 2012. Measuring the Performance of the Public Sector Using the Balanced Scorecard (Case Study of the South Sumatra DGT Regional Office Forum Bisnis dan Kewirausahaan. Jurnal Ilmiah STIE MDP.

[6] Kaplan, S. R. \& Norton, P. D. 2000 Menerapkan Strategi Menjadi Aksi Balanced Scorecard. Erlangga.

[7] Regulation of the Minister of Administrative Reform and Bureaucratic Reform of the Republic of Indonesia Number 53 of 2014 concerning Technical Guidelines for Performance Agreements, Performance Reporting and Procedures for Reviewing Government Agency Performance Reports and Performance Agreements.

[8] Niven, P. R. 2006. Balanced Scorecard Step By Step For Government and Non Profit Agencies. John Wiley and Sons.

[9] Campbell, D., Datar, S. C. Kulp, C. \& Narayanan, V. G. 2002. Using the BSC as a control System for Monitoring and Revising Corporate Strategy. Harvard NOM Working Paper No. 02-35, pp. 1-45.

[10] Gasperz, V. 2006. Balanced Scorecard Integrated Performance Management System with Six Sigma, for Business Organizations and Government. PT. Gramedia Pustaka Utama. 